\title{
MANAGEMENT MATERI DAKWAH DALAM PERKEMBANGAN MEDIA SOSIAL
}

\author{
Ajeng Wahyuni, M.Pd \\ Institute Agama Islam Negeri Ponorogo Jawa Timur \\ Ajengwahyuni@yahoo.com
}

\section{ABSTRACT}

Indonesian society is currently experiencing changes in the context of the missionary movement. A da'i celebrity in her missionary activities has not been oriented towards the resulting impact. Research on organizing da'i's da'wah message has the purpose of knowing the organization of messages in preaching. Based on the theme raised in this study formulate a problem about how to construct da'wah messages, how to form Al Habsyi's da'wah messages. Relevant to the objectives, this study uses qualitative methods with a case study approach. Da'wah messages conveyed by cleric Al Habsyi namely mubasyaroh. Organizing messages by increasing the attention of mad'u, through nasyid, the needs of mad'u, fulfillment of the material of mad'u preaching on religious messages, describes the contents of the message of da'wah, through stories. Utilizing stories and taking actions with persuasive communication, namely by carrying out the Sunnah.

Keywords: Organizing, Da'wah Message, $D a^{\prime} i$ 


\section{A. PENDAHULUAN}

Fenomena baru dalam aktivitas dakwah di Indonesia adalah munculnya kesan dakwah lebih menguntungkan para $d a^{\prime} i$ dibandingkan dengan masyarakat yang mendapat seruan dakwah. Fenomena ini mungkin dikarenakan dengan munculnya $d a^{\prime} i$ yang mengalami peningkatan status sosial setelah menjadi juru dakwah dan diterima di majelis-majelis ilmu atau pengajian. $D a^{\prime} i$ yang sudah memiliki nama ditengah masyarakat secara otomatis status sosialnya juga meningkat, terkenal dan dalam segi ekonomi juga meningkat, namun pesan-pesan dakwah yang telah disampaikannya kurang berdampak terhadap mad'u. Dilihat dari segi sosiologis, proses dakwah Indonesia mampu memunculkan struktur masyarakat baru dimana para muballgih/da'I menjadi elite sedangkan masyarakat yang menjadi objek dakwah tetap miskin dan berada pada kasta rendah.

$D a^{\prime} i$ yang telah memiliki posisi ditengah-tengah masyarakat kemudian mendapat kesempatan atau diundang untuk mengisi sebuah pengajian di media televise, dari sinilah da'I mulai . Popularitas $d a^{\prime} i$ inilah yang kemudian menjadi label $d a^{\prime} i$ selebriti. Identiknya $d a^{\prime} i$ selebriti memberikan tarif mahal, jadwalnya padat, banyak mengisi di program televisi dan kegiatan keagamaan di masyarakat.

Padatnya jadwal da'i dalam kegiatan dakwahnya dituntut untuk memahami dan mampu mengorganisasi pesan dakwah secara cermat dan tepat. Kebanyakan $d a^{\prime} i$ mengulang satu tema yang sama untuk disampaikan pada kegiatan dakwahnya di temppat yang lain. Kebiasaan ini sebenarnya tidak dianjurkan dalam pegorganisasian pesan dakwah. $D a^{\prime} i$ dengan tarif mahal tentu dituntut untuk disiplin dan profesiaonal dalam dakwahnya. Tujuannya dapat menyampaikan pesan dakwah sesuai dengan apa yang menjadi kebutuhan masyarakat di mana $d a^{\prime} i$ berdakwah.

Tidak hanya berdakwah semata mencari popularitas dan melupakan kemampuan dalam memahami serta memiliki pemahaman luas tentang ilmu agama. $D a^{\prime} i$ yang memiliki pemahaman yang baik ini kemudian menjadi populer dengan ilmunya, maka akan bertahan lama dan memberikan kekuatan dakwah Islam. Memahami masyarakat secara menyeluruh dari beberapa aspek. Hal ini mampu menciptakan proses Menejemen pesan yang efektif.

Mengintegrasikan kondisi masyarakat dengan isi pesan dakwah merupakan tugas seorang $d a^{\prime} i$. Da'i merupakan seorang penyampai pesan-pesan ajaran Islam. Kegiatan penyampaian pesan pada kondisi masyarakat yang tidak lepas dengan permasalahan baru yang muncul. Kondisi ini tidak hanya berpengaruh pada siapa yang sedang bermasalah dan siapa yang membuat kesalahan, namun permasalahan ini juga berpengaruh terhadap kelangsungan $d a^{\prime} i$ dalam melaksanakan kegiatan dakwahnya. Seorang $d a^{\prime} i$ dalam menghadapi khalayak luas yang sedemikian komplek perlu lebih kreatif dan inovatif dalam 
mempersiapkan pesan dakwah.

Pesan dakwah atau maddah disampaikan oleh $d a^{\prime} I$ sebagai isi dalam berdakwah. Pemahaman mad'u ditentukan oleh pesan yang disampaikan $d a^{\prime} i$, sehingga dalam menyusun pesan dakwah harus dengan sistem yang baik dan sesuai dengan kondisi mad'u.Kemampuan mengidentifikasi ini kemudian akan membangun komunikasi yang efektif. Keefektifan ini muncul karena objek dakwah sudah dipahami karakternya oleh seorang juru dakwah. Ketepatan materi dakwah yang disampaikan menjadi mudah diterima semua kalangan, serta tidak memunculkan perselisihan terkait isi pesan dakwahnya.

Menejemen pesan tidak lepas dengan tujuan yang ingin dicapai oleh $d a^{\prime} i$. Sehingga perlu memperhatikan objek yang menjadi sasaran dakwahnya, selain itu juga perlu materi dakwah yang akan diolah menjadi suatu pesan dakwah yang relevan. Kemudian pesan dakwah tidak terlepas dengan penggunaan media dalam menganalisis mad'u guna tercapainya tujuan dakwah.

Pesan dakwah sering disampaikan ustad Ahmad Al Habsyi yaitu pesan yang ringan dan mudah dipahami, namun materi yang disampaikan disuatu tempat dengan tempat yang lain sering mengalami persamaan atau mengulang isi pesan dakwah yang sama. Adapun redaksinya yang berbeda tetapi masih dalam tema yang sama. Penyampaian pesan dengan lembut dan humoris ini dapat memberikan kesan tersendiri. Kesan juga didapatkan dari pakaian yang dikenakan dan gayanya.

Studi-studi sebelumnya yang berjudul pesan dakwah Hasan Al-Banna dalam buku majmu'at al-rasail, menunjukkan bahwa Menejemen pesan dakwah didasarkan pada tiga aspek yaitu, akidah dengan membangun spiritualitas, syariah dalam wacana kekuasaan, dan akhlak dengan wacana relasi sosial. Pesan dakwah dalam penelitian itu berorientasi pada pembenahan sistem kehidupan sosial yang rusak dengan upaya mengembalikan kedalam sistem Islam. Pesan dakwah tidak selalu sama pada kondisi masyarakat tertentu, sehingga isi dakwah pun relatif dengan memperhatikan apa yang menjadi kebutuhan mad' $u^{1}$.

Menejemen pesan juga dibahas dalam penelitian tentang pesan dakwah pada buletin jum'at Himmah, dapat diambil pengertian bahwa Menejemen pesan dakwah tidak lepas dengan penggunaan media cetak untuk menyampaikan dakwah kepada masyarakat. Perbedaan dalam Menejemen pesan dakwah, dalam

${ }^{1}$ M. Hanif Fuadi, "Pesan Dakwah Hasan Al-Banna dalam Buku Majmu'at al-Rasail”, Ilmu Dakwah, (Bandung: Academic Journal for Homiletic Studies), Vol. 11, No. 2/ 2017, h. 335-337 
penelitiannyadisesuaikan dengan media apa yang digunakan dalam berdakwah, sedangkan penelitian ini disesuaika dengan kondisi mad'u. Hal ini dilakukan guna menghindari dari ketidapahaman masyarakat terhadap isi pesan dakwah².

Berdasarkan pemaparan diatas dipahami bahwa dalam Menejemen pesan setiap ustadatauda'i memiliki cara berbeda-beda. Terdapat beberapa perbedaan dalam penelitian sebelumnya yaitu, pada sistem Menejemen pesan yangmenggunakan klasifikasi pendahuluan, isi pesan, dan kesimpulan. Selanjutnya, objek kajian penelitian ini yaitu seorang $d a^{\prime} i$. Menejemen pesan dakwah inilah yang kemudian menjadi menarik untuk di kaji.

\section{B. Dakwah}

Menurut bahasa kata dakwah dalam bahasa Arab terdiri dari kata: $d a^{\prime} a$, دعوة

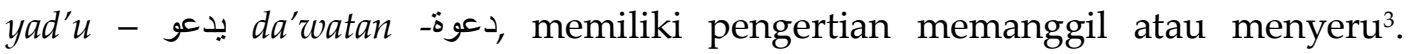
Dakwah merupakan usaha untuk merubah situasi kearah yang lebih baik, baik untuk pribadi dan baik bagi masyarakat. Dakwah tidak hanya terbatas pada peningkatan pemahaman keagamaan dan perilaku, tetapi juga mampu berperan menuju kepada pelaksanaan ajaran Islam secara kaffah. Proses mengajak dan mengundang memiliki aktivitas mempengaruhi jiwa mad'u supaya mengikuti apa yang disampaikan $d a^{\prime} i^{4}$. Seorang $d a^{\prime} i$ memiliki tujuan utama supaya efektif pesan dakwah yang disampaikannya, sehingga persiapanya juga dilakukan secara maksimal.

Dakwah merupakan kewajiban setiap muslim sebagai implikasi logis dari bentuk pengabdian kepada Allah SWT dengan penuh ketaatan. Pengabdian tersebut barang tentu menjadi tugas kita semua untuk memiliki kemampuan dalam mengorganisasi pesan dakwah.Menejemen pesan dalam berdakwah menjadi suatu hal yang wajib ketika menginginkan pesan itu diterima dan

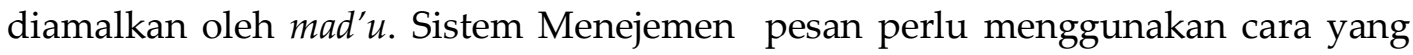
sistematis, untuk menghasilkan pesan yang menarik dan mudah dipahami. Pesan merupakan bagian inti dari proses interaksi antara komunikator dengan komunikan dalam hal ini $d a^{\prime} i$ dan $m a d^{\prime} u^{5}$.

Pesan dakwah dari segi bahasa maudlu' al-da'wah sesuatu yang disampaikan oleh $d a^{\prime} i$ kepada mad'u dalam mencapai tujuan dakwahnya. Pesan dakwah yang dimaksudkan supaya manusia dapat menerima dan memahami serta

${ }^{2}$ Haryanto, "Pesan Dakwah pada Buletin Ju'at Himmah", Jurnal Studi Agama dan Masyarakat (Palangka Raya: IAIN Palangka Raya), Vol. 12, No. 1/2016, h. 14

${ }^{3}$ Kustadi Suhandang, Strategi Dakwah, (Bandung: PT Remaja Rosdakarya, 2014) h. 21

${ }^{4}$ Enung Asmaya,"Faktor Personal dan Situasional Penerimaan Pesan Dakwah" KOMUNIKA, (Purwokerto: IAIN Purwokerto), Vol. 10, No.1/ Januari-Juni 2016, h. 48

${ }^{5}$ Ibid, h.50. 
mengamalkan ajaran Islam sebagai pedoman dalam kehidupan ${ }^{6}$.

Mad'u menerima dan memahami pesan dakwah, tentu ada cara yang digunakan seorang $d a^{\prime} i$ dalam berdakwah. Dakwah tidak hanya sekedar penyampaian informasi semata, melainkan sampai mempengaruhi dan dapat mengamalkan apa yang disampaikan atau diinformasikan. Tanggung jawab ini yang menjadi semangat para juru dakwah untuk melakukan Menejemen pesan dakwah sebelum hadir sebagai penyampai pesan kebaikan.

Pesan atau maddah merupakan segala sesuatu isi dakwah yang disampaikan oleh $d a^{\prime} i$ kepada mad'u. Isi pesan tersebut terdiri dari ajaran agama Islam di dalam Kitabullah dan Sunnah Rasul-Nya, serta pesan yang lain berisi ajaran Islam. AlQur'an dan Hadis menjadi sumber utama dalam pesan dakwah, kemudian sumber yang lain merupakan sumber penjelas atau penguat terhadap isi al-Qur'an dan Hadis. Pesan yang bersumber selain dari sumber-sumber tersebut tidak dapat di katakan sebagai isi pesan dakwah.

Secara umum materi dakwah dapat diklasifikasikan menjadi masalah pokok, diantaranya pesan akidah, meliputi keimanan kepada Allah, iman kepada malaikat-Nya, iman kepada Kitab-kitab-Nya, iman kepada Rasul-rasul-Nya, iman kepada Hari Akhir, dan iman kepada Qadha-Qadhar. Selanjutnya pesan syariah yang meliputi, kajian ibadah, muamalah. Kemudian, pesan akhlak yang terdiri dari akhlak terhadap Allah SWT dan akhlak kepada makhluk7.

Pesan yang telah disusun dengan baik kemudian menyesuaikan dengan pola pikir khalayak. Beberapa acuan yang harus di perhatikan dalam mengelola pesan dakwah sebelum disampaikan kepada mad'u. Diantaranya memahami mad'u yang dihadapi apakah didominasi perempuan, laki-laki, remaja, kemudian usia, kecerdasan, kebiasaan, motivasi dan pengalaman mad'u. Selanjutnya, budaya dan tradisi juga mempengaruhi tersampainya pesan dalam mencapai tujuan dakwah.

Dakwah merupakan tentang bagaimana menyampaikan pesan Allah kepada manusia yang menjadi tugas pokok $d a^{\prime} i$. Tujuannya mengingatkan dan mengajak semua manusia yang hidup di bumi serta memiliki potensi untuk mengubah semangat hidup manusia, perubahan yang benar-benar dalam mencari bekal di dunia sampai akhirat.

Seorang $d a^{\prime} i$ memperhatikan kondisi $m a d^{\prime} u$ dan mengklasifikasikannya, hal ini dilakukan berhubungan dengan proses menyusun pesan dakwah. Sesuai

${ }^{6}$ Nurasiah Ismail, Zainal Abidin, Uwes Fatoni, “Pesan Dakwah tentang Nikah di Media Sosial Instagram",TABLIGH(Bandung: UIN Sunan Gunung Djati), Vol. 3, No. 1/ 2018, h. 25

${ }^{7}$ Wahyu Ilaihi, Komunikasi Dakwah,(Bandung: PT Remaja Rosdakarya,2013), h.100-102 
dengan pendapat Alan H. Manroe (1930-an) tentang sistem Menejemen pesan berupa attention (perhatian), da'iharus mampu menimbulkan perhatian sehingga mad'u memiliki kesamaan dalam menghadapi permasalahan. Need (kebutuhan),membangkitkan minat dan menerangkan perlunya masalah tersebut untuk diketahui dengan menghubungkan dengan kebutuhan pribadinya dan daya tarik motif. Satisfication (pemuasan), menjelaskan pemecahan massalah tersebut dengan melihat pengalaman masa lalu, pengetahuan dan kepribadian mad'u.Visualization (visualisasi), menegaskan kembali perasaan tersebut dengan ikhtisar, tinjauan singkat, dan kata-kata pengingat serta visualisasikan. Action (tindakan) merumuskan tahap visualisai dalam bentuk sikap dan tindakan yang kongkret ${ }^{8}$.

Pesan yang baik yaitu pesan yang memiliki imbauan atau ajakan yang jelas, setiap pemberi pesan harus sesuai dengan tujuan pesan tersebut, tidak ada kesalahpahaman makna yang disampaikan. Beberapa imbauan yang dapat digunakan, misalnya imbauan rasional, imbauan emosional, imbauan motivasional, imbauan harapan, dan himbauan takut. Menggunakan imbauan tersebut pesan yang disampaikan dapat efektif dan diterima dengan baik.

\section{Langkah Penyusunan Materi Dakwah}

Sebelum menetapkan Menejemen pesan dakwah, perlu diketahui langkahlangkah atau prosedur yang harus dilakukan seorang $d a^{\prime} i$, yaitu: Survey awal tentang kondisi mad'u, menyusun strategi dan pendekatan yang akan digunakan, menetapkan standar isi atau tujuan yang akan dicapai, menyusun materi dakwah yang relevan, konsisten dan lengkap, menyiapkan media komunikasi yang tepat ${ }^{9}$.

Media dilihat dengan program tampilan yang berisi konten-konten Islam saat ini tidak begitu dominan dan masih kurang menarik. Tayangan program dakwah di media itu seperti mencari bentuk yang ideal. Berbagai metode dan konsep yang diterapkan oleh pengelola program dalam media belum menghasilkan tayangan yang menarik pemirsa. Melihat perkembangan situasi dan keadaan yang dijelaskan di atas, keterlibatan para $d a^{\prime} i$ di Indonesia terhadap Menejemen pesan dakwah atau konten dakwah di media harus disesuaikan dengan kebutuhan dan persepsi yang bersama ${ }^{10}$.

Persiapan awal sebelum melaksanakan dakwah tersebut dapat dilakukan oleh $d a^{\prime} i$, akan tetapi bisa juga tidak dilakukan. Tidak dilakukan prosedur tersebut bukan berarti tidak ada persiapan, namun langkah-langkah tersebut dilakukan

\footnotetext{
8 Jalaluddin Rakhmat, Psikologi Komunikasi,(Bandung: PT Remaja Rosdakarya, 2011), h. 259

9 Kamaluddin, 2016 "Pesan Dakwah",FITRAH: Jurnal Kajian Ilmu-ilmu Keislaman,(Padang: IAIN Padang)Vol. 2, No. 2/ Desember 2016, h. 47

${ }^{10}$ Dede Mulkan, "Islamic Peaching (Da'wa) Portrait in Television (Indonesian Cases)", The International Journal of Social Sciences, (Bandung: Universitas Padjadjaran), Vol. 19, No. 1/ Januari 2014, h. 61
} 
dengan cara spontanitas. Ada sisi baiknya ketika prosedur itu dilakukan secara spontan, karena mengetahui langsungmad'u, sehingga dapat menyesuaikan pesan yang di sampaikan secara tepat sasaran.Menejemen pesan harus dilakukan dengan cermat dan dinamis.

Menejemen pesan dakwah ustad Habib Ahmad Al Habsyi yaitu menggunakan strategi (manhaz), yaitu strategi mubasyaroh (langsung) melihat, menatap mad'u, kemudian langsung terpikir materi apa yang cocok untuk disampaikan dengan kondisi tersebut atau sering disebut defence in the condition. Pesan yang disampaikan merupakan pesan yang secara sepontan dipersiapkan dalam jangka pendek, hal ini dilakukan untuk mengantisipasi perubahan keadaan $m a d, u$ dan komposisi pesan yang ingin disampaikan. Faktor inilah yang kemudian menjadi cara yang tepat dan menarik untuk dilakukan.

Mengetahui kondisi mad'u di lapangan memungkinkan $d a^{\prime} I$ untuk menemukan ide pesan yang akan disampaikan.Semisalnya pada kajian yang jamaahnya kaum perempuan, maka yang diangkat yaitu bab tentang perempuan. Direct sharing ini yang kemudian menjadi menarik dan memiliki kesan tersendiri. Intinya adalah sampaikan dakwah itu dari hati menuju ke hati dan apapun yang berangkat dari hati maka akan berkesan di hati serta hati-hati bawa hati.

formulasi sistematika Menejemen pesan dakwah sebagaimana yang dikemukakan Alan H. Monroe: "Monroe's motivated sequence states that on the firs step is to state the problem the customer is having, then explain it if one cannot solidify the need and give a representation of the situation that may occur"11. Langkah-langkah memotivasi menurut Monroe, yang menyatakan bahwa langkah pertama yaitu menyatakan masalah yang dialami masyarakat, menjelaskan jika seseorang tidak dapat memenuhi kebutuhan dan memberikan representasi dari keadaan yang mungkin dapat terjadi.

Pertama tahapan perhatian, yaitu membangkitkan perhatian khalayak terhadap ide yang ditawarkan dengan menggunakan cerita mendetail, contoh mengejutkan, statistik dramatis, kutipan dan lainnya. Ustad Al Habsyi membangkitkan perhatian dengan menggunakan ucapan salam dengan menggunakan alunan nasyid. Nasyid ini dinilai efektif sebagai media pendukung dalam berdakwah, yang demikian karena masyarakat di indonesia umumnya menyukai hal semacam itu.

Dakwah dengan media nasyid ini cukup signifikan perkembanganya. Nasyid yang berarti senandung terdapat pesan-pesan dakwah untuk selalu

${ }^{11}$ Monroe, A. H., Monroe's Principles of Speech, (Scott: Foresman, 1943) 
mengingat Allah SWT. Manusia mengingat dan menaati perintah dan menjauhi larangan-Nya sesuai yang terkandung dalam al-Qur'an dan Hadits.Tidak hanya itu nasyid mampu menjadi perjuangan umat muslim dalam memerangi perkembangan musik barat yang bernuansa tidak sesuai dengan kepribadian umat muslim.

Kedua, tahapan kebutuhan. Tahap ini menunjukkan tema yang disampaikan berlaku untuk kebutuhan psikologis khalayak. Premisnya bahwa audiens adalah apa yang memotivasi tindakan. Melebihi dari menetapkan ada suatu permasalahan yang signifikan. Ada masalah yang tidak sesuai dengan kondisi audiens. Tunjukkan bahwa kebutuhan tidak akan hilang dengan sendirinya, dengan menunjukkan contoh dan semacamnya, sehingga meyakinkan audiens bahwa mereka memiliki kebutuhan pribadi yang kemudian mengambil tindakan. Hal ini $d a^{\prime} i$ membangkitkan rasa kebutuhan khalayak terhadap gagasan yang ditawarkan sesuai dengan tujuan dakwah.

Menejemen bagian isi pesan harus disusun dengan menyertakan ilustrasinya dengan contoh yang sedang menjadi topik hangat dalam masyarakat. Penjelasannya pun menggunakan bentuk perskripsi atau langkah-langkah, dan penjelasan singkat. Tujuannya untuk memudahkan dalam memahaminya serta tidak ada kalimat yang terlewat untuk di pahami secara efektif. ${ }^{12}$. Pemahaman terhadap materi yang disampaikan tentu melibatkan pelaku dakwah dan khalayak yang menjadi objek dakwah.

Tahapan yang ketiga, yaitu tahapan pemuasan. Penyelesaian masalah yang diharapkan mad'u. Memberikan solusi secara spesifik, sehingga dapat diterapkan oleh individu maupun komunitas untuk memecahkan masalah. Tahapan ini berisi tentang penawaran solusi dan upaya pemenuhan kebutuhan terhadap masalah yang dirasakan oleh mad'u.

$D a^{\prime} i$ harus meyakini bahwa dakwah merupakan tugas mulia. Komitmen ini harus dimiliki seorang $d a^{\prime} i$, untuk dapat berjuang dengan tangguh di medan dakwah. Tidak mudah menyerah lantaran tantangan yang dihadapi dipandang sulit. $D a^{\prime} i$ pantang untuk membeda-bedakan tempat berdakwah, ia harus siap dan ikhlas mengemban tugas dimanapun. Hakekatnya Tuhan orang beriman itu sama, kapanpun, dan dimanapun ia berada.

Keempat, tahapan visualisasi, yaitu memberitahu mad'u tentang apa yang akan terjadi jika solusi yang diberikan kemudian dilaksanakan dan tidak dilaksanakan. Visualisasikan secara detail untuk mengantisipasi terjadinya kesalahpahaman dalam memproyeksikan gagasan ke masa yang akan datang.

12 Ratna Dewi Luwita, "Strategi Penyusunan Pesan Undas.co dalam Meningkatkan Kepedulian Remaja pada Industri Kreatif Lokal Kota Samarinda",Ejournal Ilmu Komunikasi(Samarinda:Universitas Mulawarman), Vol. 4, No. 2/ 2016, h. 299 
Menggambarkan kepada suatu kebaikan ketika gagasan yang disampaikan dapat diimplementasikan dalam kehidupan sehari-hari.

Tahapan yang terakhir yaitu tahapan tindakan, dengan memberitahu mad'u tindakan apa saja yang dapat mereka laksanakan dan digunakan untuk menyelesaikan permasalahan yang dihadapi. Tahap ini dilakukan dalam komunikasi lisan atau berdakwah yang bersifat persuasif. Sering ustad Al Habsyi mengkritik mad'u untuk melaksanakan apa yang diperintahkan, namun dikemas dengan cara yang unik dan menarik. Bahkan metode ini disebut metode mengkritik terasa kripik. Maksudnya adalah menasehati khalayak tanpa terasa mereka di nasehati tetapi mereka melakukan dengan senang hati tanpa disadari dan tidak ada paksaan.

Memperhatikan kelemahan dari mad'u serta menutupinya dengan faktor sosial yang relevan merupakan langkah efektif dalam berdakwah, yang memiliki peluang besar untuk diterima dakwahnya ${ }^{13}$. Mengintegrasikan pemahaman $d a^{\prime} i$ dengan mad'u inilah yang tidak banyak dimiliki oleh kalangan $d a^{\prime} i$ ataupun ahli komunikasi. Membangun spiritualitas atau kesadaran batin (inner awarennes), gambaran integrasi personal (personal integration). Spiritualitas inilah yang kemudian menjadi fondasi awal setiap manusia dalam menjalin hubungan baik antar sesamanya. Terciptanya persatuan dan kesatuan pemahaman dengan apa yang menjadi tujuan bersama dalam meraih kebahagiaan dan keselamatan ${ }^{14}$.

Keteguhan dan keuletan dalam memperjuangkan tugas mulia ini harus ada dalam kepribadian muslim. Muslim bergerak dan mendukung aktivitas gerakan dakwah Islam tanpa mengintimidasi gerakan-gerakan yang bernuasa Islam. Kekuasaan yang dimiliki kemudian dijadikan alat untuk memperjuangkan agama Islam, sehingga kekuatan penyampaian pesan dakwah tidak terbatas pada Menejemen yang dilakukan seorang $d a^{\prime} i$ saja, melainkan tanggung jawab bersama.

Banyaknya intimidasi dan larangan atas gerakan dakwah Islam ini yang kemudian memunculkan beberapa permasalahan. Cara seperti itu yang dapat melemahkan kekuatan umat muslim dalam kegiatan dakwah. Tak dipungkiri bahwa setiap muslim memiliki pendapat yang berbeda, namun ketika perbedaan tersebut di akomodasi dengan baik maka akan menjadi kekuatan yang begitu besar. Tentu saja akan meningkatkan ghirah (semangat) berlomba-lomba dalam meraih kebaikan.

Kekuatan yang semacam ini yang tidak banyak disadari oleh banyak umat muslim. Kepentingan pribadi yang lebih diutamakan dibanding kepentingan

\footnotetext{
${ }^{13}$ Asmaya, Faktor Personal, h.60

${ }^{14}$ Fuadi, Pesan Dakwah, h. 336
} 
umat. Melihat berbagai permssalahan namun tetap membiarkan bahkan tanpa kepedulian. Melihat kemungkaran dimana-mana, namun dianggap biasa saja. Sikap semacam ini tidak bisa dibiarkan hingga merambah pada generasi berikutnya.

\section{Menejemen Pesan Dakwah}

Pesan dakwah merupakan pesan yang isinya muatan dakwah, yaitu muatan tentang amar ma'ruf nahi munkar ${ }^{15}$. Baik itu disampaikan secara jelas maupun secara kiasan. Dakwah tanpa pesan memang tidak memiliki makna apa-apa, tetapi dakwah juga tidak semena-mena pesan, melainkan juga kapan harus disampaikan, kepada siapa disampaikan, siapa yang menyampaikan, melalui media apa dan seterusnya ini yang dapat menyempurnakan kegiatan dakwah.

Penyampaian pesan dakwah tidak lepas dengan kisah, baik kisah yang terdahulu, sekarang ataupun kisah yang akan datang. Bercerita kisah itu penting, kisah mampu menguatkan hati, karena di dalam al-Qur'an terdapat 3/4 bagian tentang kisah. Sebagaimana dicontohkan Rasulullah yang tidak menggunakan kisah dalam menyampaikan visi dan misinya. Melalui kisah-kisah tersebut, maka masalah berburuk sangka kepada Allah dapat diatasi, dengan memberi pemahaman sesuai dengan peristiwa yang terjadi.

Sumber pesan dakwah ada dua jenis, yaitu pesan yang dicari melalui penelitian empiris dan laboratoris. Kedua jenis pesan yang diberikan Tuhan lewat para Nabi dan Rasul. Pesan yang ditemukan dari hasil penelitian ini kemudian menjadi ilmu - ilmu sosial dan sains teknologi. Sedangkan pesan yang bersumber dari wahyu, ini kemudian menjadi ilmu agama. Keduanya dapat digunaan sebagai isi pesan dakwah sesuai dengan yang diinginkan ${ }^{16}$.

Penekanan pesan dakwah salah satunya yaitu dilakukan dengan hikmah, yaitu perkataan yang jelas dan benar. Terdapat dalam QS. Yusuf (12) ayat 108, "katakan: inilah jalan (agama)-ku, aku dan ordang-orang yang mengikutiku mengajak (kamu) kepada Allah dengan hujjah yang nyata. Maha Suci Allah, dan aku tiada termasuk orang-orang yang musyrik."

$D a^{\prime} i$ dalam mengemukakan hasil penelitian harus jelas dengan menyebutkan kualifikasi penelitian dan tahun penelitian, dimaksudkan untuk menilai kredibilitas suatu penelitian yang dapat dijadikan rujukan sumber pesan dakwah. $D a^{\prime} i$ dianggap tidak menggugah (striking) dan tidak meyakinkan (convincing)jika tidak ditopang dengan data hasil-hasil penelitian dalam materi yang terkait data empiris.

Sumber pesan dakwah yang berasal dari wahyu, yang utama adalah AlQur'an. Al-Qur'an disamping sebagai sumber pesan dakwah, juga memiliki fungsi penting dalam kehidupan, yakni sebagai kitab petunjuk (hudan), pemisah

${ }^{15}$ Sujatmiko, "Pesan Dakwah dalam Lagu "Bila Tiba".KOMUNIKA, Vol. 9, No. 2/ 2015, h. 181-195.

${ }^{16}$ Kamaluddin, Pesan Dakwah, h.40 
antara yang haq dan yang bathil (furqan), pembenar dan standar ujian atas kitab suci (musaddiq dan muhaymin), pembawa rahmat (rahmat), penawar penyakit (syifa'), pembawa pencerahan ${ }^{17}$.

Disamping al-Qur'an, hadits termasuk pesan pokok dakwah, hadits menempati posisi kedua setelah al-Qur'an. Hadits tidak bertentangan dengan alQur'an, akan tetapi melengkapi dan sebagai pendukung isi dalam al-Qur'an sebagai sumber utama. Seorang $d a^{\prime} i$ tentu tidak akan kekurangan isi pesan dakwah yang akan disampaikan, karena terdapat banyak sumber yang dapat digunakan serta diolah sebagai pesan dakwah yang berkualitas dengan sumbersumber terpercaya. Penekanannya bertujuan untuk menjaga semua materi yang disajikan dalam aktivitas dakwah berdasarkan konsep Islam, yaitu al-Qur'an dan Sunnah ${ }^{18}$.

Perkembangan saat ini tidak terlepas dengan permasalahan yang komplek. Munculnya masalah-masalah kontemporer tentu diperlukan sebuah pesan yang memiliki penafsiran sesuai dengan permasalahan yang terjad saat ini. Penafsiran yang tepat akan memberikan sebuah penyelesaian masalah (problem solving) serta jawaban atas masalah kontemporer yang dihadapi masyarakat. Pengembangan ini dapat dilakukan dengan mengembangkan sifat pesan dakwah. Sifat pesan dakwah ini dapat diambil dari al-Qur'an dengan menggunakan pendekatan komunikasi.

Menurut Enjang AS, dakwah pada era sekarang tidak hanya dipahami dengan penyampaian pesan Islam melalui mimbar, ceramah, khutbah di mimbar saja, tetapi berbagai aktivitas keislaman yang memmberikan motivasi, teladan baik tulisan maupun lisan (ahsanuqaulan) dan berupa perbuatan nyata (ahsanuamalan) ${ }^{19}$. Bentuk dan model dakwah semacam ini yang harus dimiliki oleh $d a^{\prime} i$, selain hanya sekedar menyampaikan pesan saja. $D a^{\prime} i$ sebagai teladan dan memiliki kharisma dalam dakwahnya.

Ciri khas dan kharismatik $d a^{\prime} I$ berpengaruh terhadap pesan dakwah yang disampaikan. Ada beberapa da'i terkadang lepas kendali dengan Menejemen pesan dakwah. Menyampaikan dengan menyelipkan humor, tetapi humornya yang mendominasi isi pesan dakwah yang diterima khalayak. Kesalahan ini yang

17 Jafar, Bentuk-bentuk Pesan, h. 49-53

${ }^{18}$ M. Siagian, "The Position of Da'wah Messages and Ethics in Malaysian an Indonesian Television Programs",Malaysian Journal of communication, Jilid 32, No.2/ 2016, h. 761

${ }^{19} \mathrm{M}$. Ghozali Moenawar dan Tata Septayuda, "Komunikasi Profetik dan Pesan Dakwah dalam Film Habibie dan Ainun", Jurnal Komunikasi,(Bandung: UIN Sunan Gunung Djati), 2015 h. 213 
kadang tidak disadari, yang disebabkan tujuan dakwah yang disusun tidak berorientasi dalam amar ma'ruf nahi munkar.

\section{E. Simpulan}

Menejemen pesan dakwah terbagi dalam beberapa tahap. Tahap pertama, yaitu membangkitkan perhatian mad'u, Tahapan kedua adalah memberikan isi pesan dakwah yang sesuai dengan kebutuhan mad'u yang ada dalam dakwahnya. Tahapan ketiga yaitu memberikan pemuasan berupa solusi terhadap masalah yang seang dihadapi oleh mad'u, dalam hal ini dilakukan pengamatan kepada mad'u sehingga pesan dakwahnya sebagai problem solving. Tahapan yang keempat, yaitu menggambarkan dengan kisah-kisah terdahulu, sekarang dan kisah yang akan datang. Tahapan yang terakhir yaitu menekankan pada tindakan atau pengamalan atas pesan yang disampaikan dengan mengemas berupa komunikasi persuasif. Rumusan pesan tersebut mampu memberikan hasil signifikan terhadap perkembangan dakwah, terlebih mampu diimplementasikan oleh khalayak luas.

Penelitian selanjutnya diharapkan mampu menggali informasi tentang strategi $d a^{\prime} i$ dalam mengembangkan dakwah secara signifikan serta mampu mengungkapkan faktor yang menghambat perkembangan dakwah.

\section{DAFTAR PUSTAKA}

Asmaya, E. (2016). Faktor Personal dan Situasional Penerimaan Pesan Dakwah. Komunika, Vol. 10, No. 1, 46-66.

Fuadi, M. H. (2017). Pesan Dakwah Hasan Al-Banna dalam Buku Majmu'at alRasail. Ilmu Dakwah: Academic Journal for Homiletic Studies, Vol. 11, No. 2, 325-340.

Habsyi, U. A. (2018, November Rabu). Menejemen Pesan Dakwah. (B. Ariyanto, Interviewer)

Haryanto. (2016). Pesan Dakwah pada Buletin Ju'at Himmah. Jurnal Studi Agama dan Masyarakat, Vol. 12, No. 1, 1-14.

Ilaihi, W. (2013). Komunikasi Dakwah. Bandung: PT Remaja Rosdakarya.

Jafar, A. (2018). Bentuk-Bentuk Pesan Dakwah dalam Kajian Al-Qur'an. Jurnal Komunikasi Islam, Vol. 8, No. 1, 41-66.

Kamaluddin. (2016). Pesan Dakwah. FITRAH: Jurnal Kajian Ilmu-ilmu Keislaman, Vol. 2, No. 2, 37-58. 
Luwita, R. D. (2016). Strategi Penyusunan Pesan Undas.co dalam Meningkatkan Kepedulian Remaja pada Industri Kreatif Lokal Kota Samarinda. Ejournal Ilmu Komunikasi, Vol. 4, No. 2, 292-305.

M. Ghozali Moenawar dan Tata Septayuda. (2015). Komunikasi Profetik dan Pesan Dakwah dalam Film Habibie dan Ainun. Jurnal Komunikasi, 211-220. Maskur dan Irfan Noor. (2014). Ustad Selebriti Abdullah Gymnastiar dalam Budaya Populer ( Perspektif Hipersemiotika Yasraf Amir Piliang). Studia Insania, 47-57.

Moleong, L. J. (2008). Metode Penelitian Kualitatif. Bandung: PT Remaja Rosdakarya. Monroe, A. H. (1943). Monroe's Principles of Speech. Scott: Foresman.

Mulkan, D. (2014). Islamic Peaching (Da'wa) Portrait in Television (Indonesian Cases)). The International Journal of Social Sciences, Vol. 19, No. 1, 55-64.

Nurasiah Ismail, Zainal Abidin, Uwes Fatoni. (2018). Pesan Dakwah tentang Nikah di Media Sosial Instagram. Tabligh: Jurnal Komunikasi dan Penyiaran Islam, Vol. 3, No. 1, 22-45.

Putri, Z. (2018). Kisah Sony yang Selamat dari Tragedi Lion Air JT 610. Jakarta: Detik.com, diakses pada tanggal 01 Desember 2018, pukul 14.30 WIB.

Rahim, U. A. (2017). Pesan Komunikasi Dakwah dalam Petatah-Petitih Minang. Jurnal Sosial Budaya, Vol. 14, No. 1, 63-79.

Rakhmat, J. (2011). Psikologi Komunikasi. Bandung: PT Remaja Rosdakarya.

Siagian, M. (2016). The Position of Da'wah Messages and Ethics in Malaysian an Indnesian Television Programs. Malaysian Journal of communication, Jilid 32, No.2, 749-769.

Siagian, S. P. (2005). Organisasi, Kepemimpinan dan Perilaku Organisasi. Jakarta: CV Haji Masagung.

Suhandang, K. (2014). Strategi Dakwah. Bandung: PT Remaja Rosdakarya.

Sujatmiko, I. (2105). Pesan Dakwah dalam Lagu "Bila Tiba". Jurnal Komunika, Vol. 9, No. 2, 181-195. 